Kirja-arvio

\title{
Spirituaalisen prosessin etnografiaa
}

Raunola, Ilona. 2018. Tulkintoja valosta ja henkisyydestä: Etnografinen tutkimus uususkonnollisesta Valorukous-toiminnasta. Joensuu: Itä-Suomen yliopisto. 70 sivua + 3 artikkelia. http://urn.fi/URN:ISBN:978-952-61-2918-1

\section{Tuija Hovi}

$\mathrm{U}$ skonnolliset perinteet eivät ole pysyviä vaan elävät ja muuttuvat dynaamisessa suhteessa aikaansa ja ympäristöönsä. Alkuperäistä ja mihinkään sekoittumatonta uskontoa voidaan tuskin koskaan jäljittää. 'Uususkonnollisuudesta' ja 'uushenkisyydestä' alettiin uskonnon tutkijoiden keskuudessa keskustella pontevammin 1990-luvun alussa, kun kiinnostuttiin siitä, miten perinteisinä pidetyt uskonnollisuuden muodot sopeutuvat ja muuttuvat uusissa yhteiskunnallisissa tilanteissa ja sisällyttävät itseensä uusia kulttuurisia vaikutteita.

Ilona Raunolan viime vuonna ilmestynyt uskontoantropologian alan väitöskirja Tulkintoja valosta ja henkisyydestä. Etnografinen tutkimus uususkonnollisesta Valorukous-toiminnasta on tutkimus, joka liikkuu uus-

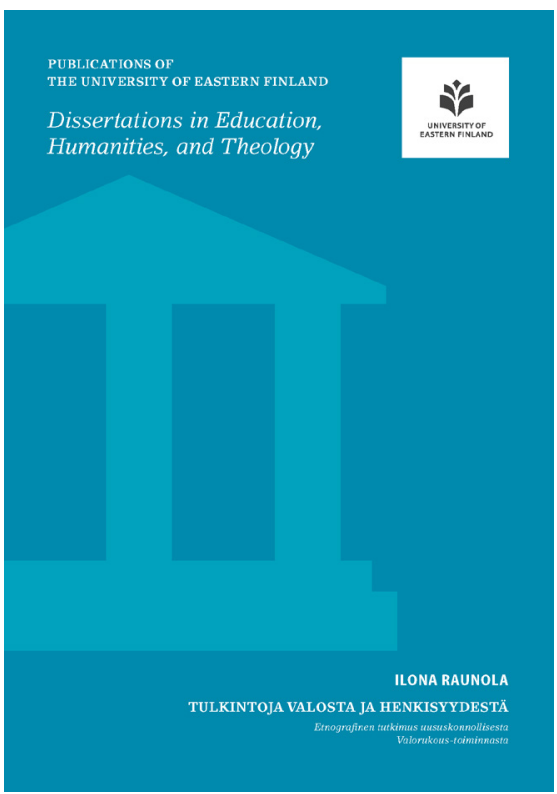
uskonnollisuuden ja uushenkisyyden kentällä 2000luvun alun Suomessa. Tämän tutkimuksen kohteena on ollut ilmiö, joka klassisessa uskontososiologisessa uskonnollisten yhteisöjen luokituksessa olisi ollut varsin helppo sijoittaa kategoriaan "kultti" siksi, että kysymyksessä oli niin opillisesti kuin toiminnallisestikin hyvin vapaamuotoinen ja joustava yhden kannattajasukupolven yhteisö. Raunola on kuitenkin harkitusti hylännyt jo aikansa eläneen kategorisoivan lähestymistavan ja tarkastellut tutkimuskohdettaan eletyn uskonnon ja kokemuksellisuuden näkökulmasta antropologin otteella. 


\section{Tutkimuskohde ja aineisto}

Tutkimuksen pääkysymyksenä on, mitä Valorukous merkitsi niin siihen osallistuvien, itse toiminnan kuin tutkimuksenkin kannalta. Lisäksi on tarkasteltu sitä, miten uususkonnollisuutta tuotetaan toimijaverkoissa ja mikä suhde henkisyydellä on uskontoon.

Väitöskirja rakentuu kahdesta suomenkielisestä ja yhdestä englanninkielisestä tutkimusartikkelista sekä itse ilmiötä ja teoreettista lähestymistapaa taustoittavasta johdannosta. Kolme artikkelia tarkentuvat omiin kysymyksiinsä. Ensimmäinen artikkeli pohtii Neitsyt Marian merkitystä Valorukouksen koostamisessa ja ylläpitämisessä. Toinen artikkeli selvittää, minkälainen merkitys spirituaalisella prosessilla oli Valorukouksen osallistujille. Kolmannessa artikkelissa tutkija on paneutunut omaan osuuteensa tutkimansa Valorukouksen toimijaverkossa.

Valorukousta on tarkasteltu osana Suomen uskonnollista kenttää. Siinä Valorukous sijoittui yhteisöllisesti liikkuvana ja notkeana uskonnollisia ja henkisiä perinteistä yhdistävänä toimintamuotona mystiikan ja hiukan jopa askeesinkin alueelle. Kaikki osallistujat eivät kuitenkaan olleet yhtä mieltä siitä, tuliko Valorukousta tarkastella uskontona vai ei. Valorukouksen kohdalla käy varsin selvästi ilmi uskontotieteellisen yhteisöluokittelun haastavuus käytännössä. Valorukoukseen sisältyi selvästi uskonnollisia elementtejä mutta sitoutumattomana toimintana siinä haluuttiin sanoutua irti uskonnosta.

Valorukous oli seitsemän vuoden ajan, aina vuoteen 2012 asti elänyt toimintamuoto ajoittain retriiteissä kokoontuvalle yhteisölle. Valorukous tarkoittaa tekijän mukaan sekä itse työmuotoa että sanatonta rukoushetkeä hiljaisuudessa. Sitä käytettiin myös nimenä työmuodon perustajien, suomalais-saksalaisen pariskunnan, Helena ja Mikael Blankan rummutukselle yhteisön tilaisuuksissa. Raunola oli osallistujana mukana viidessä retriitissä, jotka järjestettiin eri maissa. Hän luonnehtii Valorukousta nomadiseksi ja liittää siihen vahvoja pyhiinvaelluksen piirteitä.

Aineistona tutkimuksessa on tutkijan itsensä retriiteissä koostama empiirinen materiaali. Se perustuu osallistuvalle havainnoinnille, haastatteluille, muistiinpanoille ja valokuville. Aineistoa, niin haastatteluja kuin kuvitustakin on päätynyt myös elävöittämään artikkeleiden analyysejä. Omaa uskontoetnografiaansa Raunola reflektoi kolmannessa artikkelissaan eläytymisen ja etääntymisen vuorotteluna ja pohtii kaksoisrooliaan Valorukouksen osallistujana ja tutkijana.

\section{Valorukouksen toimijaverkko}

Raunolan tutkimus osallistuu yhden empiirisen esimerkin avulla keskusteluun siitä, miten uususkonnollisuutta tuotetaan toimijaverkoissa ja mikä suhde henkisyydellä on uskontoon. Se sijoittuu näin keskusteluun, jota on käyty varsin vilkkaasti uskontotieteilijöiden keskuudessa kuluvan vuosikymmenen aikana.

Melko pitkän ja perinteisen etnografisen kenttätyön käynnistämän tutkimusprosessin kuluessa ja aineistonsa ohjaamana Raunola on päätynyt tutkimaan Valorukousta kaikkien siihen kuuluvien elementtien vuorovaikutuksena. Hän soveltaa analyysissään Bruno Latourin toimijaverkkoteoriaa. Toimijaverkkoteorian mukaan toimijuus kytkee 
inhimilliset ja ei-inhimilliset oliot yhteiseen interaktiiviseen merkitysten ja keskinäisten riippuvuussuhteiden verkostoon.

Valorukouksen toimijaverkossa merkityksellinen toimijuus toteutuu inhimillisten toimijoiden eli retriitteihin osallistuvien ihmisten ja Valorukoukselle keskeisten materiaalisten elementtien vuorovaikutussuhteina. Ensimmäisessä artikkelissa tarkasteltu Neitsyt Marian hahmo näyttäytyy keskeisenä toimijana Valorukouksen harjoittajille. Maria-valokuvat ja -käsitykset punovat verkkoa inhimillisten ja ei-inhimillisten toimijoiden välille. Kuvan rooli Valorukouksessa oli verrattavissa ihmissuhteeseen. Marian hahmoa ei kuitenkaan sidottu katoliseen kristillisyyteen vaan ylipäänsä henkiseen opettajuuteen. Marian kuva oli samanaikaisesti sekä Valorukous-toiminnan kohde että siinä mukana oleva aktiivinen toimija. Monitulkintaisuus ja kritiikki perinteisiä Maria-tulkintoja kohtaan heijastuivat haastateltavien mietteissä.

\section{Spirituaalista prosessia tutkimassa}

Toisessa artikkelissa Raunola on syventynyt Valorukoukseen henkisenä ja hengellisenä prosessina. Valorukous oli yhdistelmä kristinuskoa - Neitsyt Maria keskeisenä figuurina - esoteriaa, New agea ja Intian uskontojen meditaatioperinteitä. Valorukouksen harjoittamisen tavoitteena oli tulla avoimeksi itselle, sisimmälle. Retriiteissä kuvattu hiljaisuuden ja valon keskeisyys tuovat mieleen myös protestanttisten kveekareiden hartauden harjoittamisen muotoja.

Raunola on keskittynyt spirituaalista retoriikkaa analysoidessaan New agen piiristä tuttuihin 'minä olen'-lauseisiin. Ne toimivat Valorukouksessakin henkisen prosessin menetelmänä yhdistettyinä mielen ja hengityksen harjoituksiin. Tulirituaaliin puolestaan liitettiin anteeksiannon teema.

Kiinnostavana piirteenä mukana tutkimuksessa on kirjallisuuden merkitys osallistujille. Valorukouksen osallistujat olivat ilmeisen innokkaita uskonnollisen ja henkisen kirjallisuuden lukijoita, ja Raunola on keskusteluttanut heitä lukukokemuksista retriittien aikana.

Kolmas, kenttämetodologiaa käsitteleva artikkeli on tutkimuksen vanhin. Se kertoo siitä, että tutkimus Valorukouksesta on vahvasti aineistolähtöinen ja etnografian ehdoilla muotoutunut. Raunola pohtii osallisuuttaan ja dialogista paikantumistaan Valorukouksessa. Osallisuus jäsentyi monitahoisena neuvotteluna tutkijan paikasta, sen antamisesta ja ottamisesta. Tekijä pohtii osallistumisen intensiteetin merkitystä sekä sitä, missä määrin ja miten hänen osallisuutensa näkyi yhteisön toiminnassa.

\section{Yksilölliset kokemukset ja vuorovaikutus}

Ilona Raunolan tutkimus Valorukouksesta sijoittuu sijoittuu etnografisen ja tulkinnallisen antropologian traditioon. Sen lähtökohtana on ollut tutkijan kokemus ja vuorovaikutus kohteensa kanssa sekä tutkitun ilmiön mahdollisimman tarkka, "tiheä" kuvaus. Valorukousta on tarkasteltu toimijaverkkoteorian valossa vuorovaikutuksena inhimillisten ja ei-inhimillisten toimijoiden kesken. 
Kuvaillessaan Valorukouksen muotoja ja merkityksiä Raunola ei ole käyttänyt uskonnon tutkimuksessa jo rehabilitoitua synkretismin käsitettä kuvaamaana toimintamuodon rakentumista erilaisia traditioita ja ideoita yhdistellen. Toisaalta Valorukouksella ei sinänsä ole omaa traditota ja osallistujat tuntuivat ymmärtävän siihen yhdistetyt kristilliset ja itämaiset elementit kukin omilla tavoillaan.

Yhtenä piiirteenä Valorukoukseen vaikutti kuuluvan myös "valolla elämisen" periaate. Ideana se lähentää Valorukousta myös kohti asketismin teemaa. Valolla eläminen on jäänyt kuitenkin tutkimuksessa katveeseen pelkkänä mainintana. Ehkä kysymys oli lopultakin hyvin yksilöllisestä kokemuksesta, jota osallistujat yleisesti eivät edes tavoitelleet.

Tutkimuskohteena Valorukouksen kaltainen löyhästi sitoutunut, liikkuva yhteisö sekä opillisesti notkea ja monitulkintainen ilmiö ei avaudu helposti tutkittavaksi. Ilona Raunola on lähestynyt kenttäänsä ruohonjuuritasolta käsin etnografian ja dialogisen tutkijuuden kuvakulmista. Tutkimus on mielenkiintoinen analyysi toimijuudesta ja merkityksenannosta yksilöllistä kokemuksellisuutta tukevassa uskonnollis-henkisessä toimintamuodossa. Kaikessa sallivuudessaan Valorukous ei lujittunut selvärajaiseksi toimintamuodoksi tai jatkunut retriittiliikkeenä. Siitä huolimatta, kuten tutkija itse toteaa, se tuotti merkittävän määrän henkisiä tapahtumia ja kokemuksia osallistujille.

FT Tuija Hovi on uskontotieteen dosentti Turun yliopistossa. 